\title{
The Influence of R\&D Capability on the Enterprise Performance: Concurrently Discuss the Managerial Power
}

\author{
Feng $\mathrm{Gu}$ and Lin Zhang* \\ School of Accountancy, Harbin Commercial University, Harbin, Heilongjiang, \\ 150028, China \\ gufenghappy@163.com
}

\begin{abstract}
We research the influence of the managerial power on the relationship between $R \& D$ capability and the enterprise performance, and take a sample of GEM companies from the year 2010 to 2013. The results showed that: (1) The R\&D capability of enterprises is stronger, the future performance is higher; (2) Compared with the state-owned enterprises, the higher R\&D capability of the non-state-owned enterprises, has the greater positive influence on enterprise performance; (3) CEO duality may lead to much managerial power. Managerial power has a negative moderating effect on the relationship between $R \& D$ capability and enterprise performance, which weaken the technology innovation of the enterprise to promote the growth of the performance; (4) Compared with the state-owned enterprises, the managerial power of non-state-owned enterprises has a more negative moderating effect on the relationship between $R \& D$ capability and the enterprise performance.
\end{abstract}

Keywords: Research and development capability, Managerial power, Enterprise performance

\section{Introduction}

Report to 18th National Congress of the Communist Party has put forward the micro economic development strategy that was "encouraged technology innovation of the enterprise in core body status". Sustainable innovation capability is the key source of sustainable competitive advantage. Ultimately, enhance the performance of the corporation. In the modern company system, the position of the chairman and general manager is crucial, which affect the effect of corporate governance and the enterprise performance. In the United States and other countries, the chairman and general manager is one person account for a large proportion. But some countries don't allow the chairman and general manager is one person, such as the UK and Germany. In the organizational structure of the enterprise, top managers have the authority of decision-making and the capacity of implementation, which plays a decisive role in the enterprise R\&D investment. Upper echelons theory is that the personal characteristics of the principal managers, including the background of the manager, managers' overconfidence heterogeneity of manager are reflected in the organization. Therefore, the decision of the manager for the $\mathrm{R} \& \mathrm{D}$ project directly affects the enterprise performance.

According to the manager's power, there are two separate views (agency theory and stewardship theory) in academic circles. Agency theory argued that the separation of two rights could supervise and balance the moral risk of the managers, and stewardship theory thought that giving managers the full authority is beneficial to form the authority, run various affairs, and enhance the efficiency of the enterprise. At present, there exists less literature on the influence of the manager's power on the enterprise's R\&D capability and

${ }^{*}$ Corresponding Author 
performance. Because development projects have the characteristics of high risk, high income and information asymmetry, it leads to more serious agency problem such as the influence on enterprise's R\&D investment efficiency and enterprise's technology innovation ability, the impact of resource allocation efficiency in Enterprise, and the impact of enterprises performance in the future. Thus, it is an important issue worthy of exploration.

The paper takes a sample of GEM companies from the year 2010 to 2013, firstly, analyze whether R\&D capability enhances enterprise performance; the next, from the perspective of the separation of board of directors and general manager, and the joining together of board of directors and general manager, analyze the influence of the power of the managers on the relationship between R\&D capability and the enterprise performance, and also analyze the difference between the state-owned enterprises and non-state-owned enterprises, for improving the allocation of the power resources, improving the efficiency of R\&D investment of the enterprise, strengthen the technology innovation ability of the enterprise, eventually it provide a theoretical foundation and empirical evidence to improve the enterprise value.

\section{Theoretical Analysis and Research Hypothesis}

\subsection{R\&D Capability and the Enterprise Performance}

Griliches (1981) study found that R\&D investment and patent technology improve enterprise value [1]. Hu and Jefferson (2004) found that the relationship between R\&D investment and performance in different industries existed significant differences [2]. Los and Verspagen (2000) view is that R\&D investment can increase the productivity of enterprises effectively [3]. Garner et al. (2002) study showed that there was a significant positive correlation between the R\&D strength of enterprise and financial performance [4]. Chang et al. (2008) study showed that the enterprise had a good internal governance mechanism which to increase $R \& D$ expenditure, had a stronger stock market reaction [5]. Chung et al. (2003) found that if the enterprise had a good supervisory mechanism, when it announced the R\&D investment, it would have a higher additional returns [6]. Hall and Oriani (2006) used the foreign manufacturing enterprises as the research sample, and found that the R\&D investment of the enterprises of French and German had a positive correlation relationship with the enterprise value [7]. There was not any correlation between the two of the enterprise of Italian. Connolly and Hirschey (2005) [8] used the data of the US enterprise and the study found that the enterprise scale had a moderating effect on the relationship between R\&D expenditures and enterprise value, the effect between $R \& D$ expenditures and the enterprise value in large enterprises is more than in small enterprises. At the same time the state-owned enterprises are in a monopoly position, and lack the motivation of the R\&D activities. But small enterprises eager to change their disadvantage in the competition through technical innovation, therefore, the higher of the R\&D capability of the non-state enterprise, and the enterprise performance is better. In the big company, such as state-owned enterprises they have a high degree of the separation of the ownership and management, and both objectives are inconsistent, and have the problem of regulatory difficulties and incomplete contract. Managers might damage the interests of shareholders to pursue their own interests so may not invest in the high efficiency of R\&D projects, and lead to insufficient investment in the high-efficiency $R \& D$ projects. In state-owned enterprises exist the phenomenon of the absence of the owner and a lower proportion of managerial ownership, and in the non-state enterprise the general manager and the owner are the same person. Managerial power is concentration. The investment purpose in the high efficiency R\&D project is clear, and which bear less constraint by the government. The R\&D capability of enterprises is 
stronger, and the future performance of the enterprise is higher. Therefore, we put forward the following hypothesis:

H1: R\&D capability of the GEM has a significant positive effect on enterprise performance. Compared with the state-owned enterprises, higher R\&D capability of non-state-owned enterprises had greater positive influence on enterprise performance.

\subsection{The Moderating Effect of Managerial Power on the Relationship of R\&D Capability and the Enterprise Performance}

From the principal agent theory perspective, because of asymmetric information and incomplete contract, agent's opportunistic behavior leads to the unification of executives' decision right and control rights, violates the principle of separation of interlinked duties, weakens independence of the board, affects organization efficiency and increases agency cost. When one person is chairman and general manager, the person has more power and less restriction, chooses anyone according to his preference, and effects on the ability of the board of directors to process and analyze spatial information. Besides, the person has the ability to information filtering, and it leads to other decision makers couldn't understand comprehensive information about the enterprise and result in drastic decisions. Under the principal agent framework, the managers have more power to defend their capital. They do not wish to carry out high-risk innovative project investment due to their risk aversion characteristics, and it effects on efficiency of R\&D project on the long-term benefits of enterprise value. Hence, they pay more attention to short-term benefits of R\&D projects. Having more $R \& D$ projects could increase available resources, be beneficial to build the empire of the manager and increase agency cost. The relationship between R\&D capability and firm performance is also impacted by other factors. Some researchers found that institutional investors have a moderating effect on R\&D expenditure and firm performance (Le et al., 2006) [9]. Other scholars found that the independence of the board of directors has a positive regulatory effect on the relationship between information technology investment and enterprise performance. R\&D projects have characteristics of high risk and high return. Shareholders tend to prefer high returns, so pay attention to $R \& D$ projects in the enterprise. However, the innovation ability of the enterprise brings out the slower benefits, and managers may take a higher risk of employment and affect on their own position and salary. Therefore, it leads to information asymmetry when managers have greater right, and management is also subject to less supervision and restraint to bring out "entrenchment effect". Management makes use of their individual rights to control the board of directors for strategic decision of enterprise innovation. So the relationship between $R \& D$ capability and enterprise performance is affected by the decision-making of management power. There is a widespread phenomenon of political connection in state-owned enterprises. And many studies have found that the political connection has optimized the internal and external environment of the enterprise, and increase the corporation value (Fisman, 2001 [10]; Johnson and Mitton, 2003 [11]; Faccio, 2006 [12]). So comparing with Non-state owned-enterprises, the negative influence of managerial power on the relationship between R\&D capability and enterprise performance will be weakened [13]. Therefore, we put forward the following hypothesis:

$\mathrm{H} 2$ : The managerial power has a negative moderating effect on the relationship between R\&D capability and enterprise performance. Compared with the state-owned enterprises, the managerial power of non-state-owned enterprises has a more negative moderating effect on the relationship between $R \& D$ capability and the enterprise performance. 


\section{Study Design}

\subsection{Sample and Data}

Index selection: in this paper, using the input oriented BCC model for the quantitative analysis of the GEM R\&D capabilities. Select the 2 indexes of the strength of R\&D Input and the intensity of technical personnel as R\&D input index, and Select the 5 indexes of the number of application patent, the number of invention patent, the ratio of intangible assets, rate of return on total assets in next period and the growth rate of operating revenue as R\&D output index. As shown in Table 1, according to the research of previous scholars, R\&D input can't affect in the current year and select lag indicators as the research output index. Since the original data exists negative, and the numerical size have differences, so we make the dimensionless of the indexes of R\&D capability. Make the dimensionless processing of the input and output indexes using using this formula: $X_{i}=0.1+0.9 \frac{x_{i}-x \operatorname{Min}}{x \operatorname{Max}-x \operatorname{Min}}$, where ${ }^{x_{i}}$ is the real value, $x \operatorname{Max}, x \operatorname{Min}$ are indicate the upper and lower limits.

Table 1. The Evaluation Index System of the R\&D Capability of GEM

\begin{tabular}{|c|c|c|}
\hline $\begin{array}{l}\text { Index } \\
\text { Type }\end{array}$ & Name of Index & Definition of Index \\
\hline $\begin{array}{l}\text { Input } \\
\text { Index }\end{array}$ & $\begin{array}{l}\text { the strength of R\&D Input } \\
\text { the intensity of technical } \\
\text { personnel }\end{array}$ & $\begin{array}{l}\mathrm{R} \& \mathrm{D} \text { input } \div \text { the income from } \\
\text { main business } \\
\text { technical personnel } \div \text { total number } \\
\text { of the personnel of the enterprise }\end{array}$ \\
\hline $\begin{array}{l}\text { Output } \\
\text { Index }\end{array}$ & $\begin{array}{l}\text { the number of application } \\
\text { patent } \\
\text { the number of invention } \\
\text { patent } \\
\text { the ratio of intangible assets } \\
\text { rate of return on total assets in } \\
\text { next period } \\
\text { growth rate of operating } \\
\text { revenue }\end{array}$ & $\begin{array}{l}\text { the total number of application } \\
\text { patent } \\
\text { the total number of invention } \\
\text { patent } \\
\text { the intangible assets } \div \text { the total } \\
\text { assets } \\
\text { total profit } \div \text { balance of total } \\
\text { assets at the end of the period } \\
\text { (the final operating income - the } \\
\text { initial operating income) } \div \text { the } \\
\text { initial operating income }\end{array}$ \\
\hline
\end{tabular}

Data Source: take a sample of GEM companies from the year 2010 to 2013 as research object, most of the GEM have the characteristics of high-tech, high-growth, high-risk. So the GME has strong innovative ability. The research process made use of the panel data, excluding the missing data sample from the year 2010 to 2013, and excluding the GME of $\mathrm{ST}, * \mathrm{ST}$ and the listing financial enterprises. At last, we received total enterprises of 143 , the data of 572 GEM. In this paper, the index of R\&D input data is obtained from manual collected for reading the annual report. The political relation data received from the CSMAR database by reading the executive resume (Jiang and Zhang, 2014). All other data are from CSMAR.

\subsection{The Analysis of the R\&D Capability of the GEM}

Table 2 listed the average efficiency of the R\&D capability of the GEM. Crste, Vrste and Scale denote respectively overall technical efficiency pure technical efficiency and scale efficiency level. The average value of three kinds of efficiency is shown in the process of a steady rise from the year 2010 to 2013, but the rise is modest. In 2011 the 
global economy is slowdown, the overall growth rate of the economy is $1.6 \%$, the growth rate of the United States, Japan, and the euro zone is respectively $1.7 \%, 1.6 \%,-0.5 \%$. Meanwhile, the growth of China's macroeconomic is also showed the signs of slowing down. Compared with the year 2010, the R\&D capability is lower in the year 2011. In 2012 and 2013, the R\&D capability of the GEM has increased, but only slightly, and it means the GEM should also improve the R\&D capability.

Table 2. The Average Level of R\&D Capability of GEM Companies

\begin{tabular}{cccc}
\hline Year & Crste & Vrste & Scale \\
\hline 2010 & 0.2669063 & 0.3190185 & 0.8331022 \\
2011 & 0.2622191 & 0.3109649 & 0.8348304 \\
2012 & 0.2744736 & 0.3191507 & 0.864186 \\
2013 & 0.2885856 & 0.3263796 & 0.8719648 \\
\hline
\end{tabular}

Among the 143 decision units, the enterprise number of the R\&D effectiveness of decision making units is respectively two, three, one, eight, from the year $2010 \sim 2013$. The comprehensive technical efficiency value is 1 ; the remaining enterprises decision making units were not achieve effective $R \& D$ investment. It means the insufficient $R \& D$ investment efficiency phenomenon of GEM is common. Improve the $R \& D$ investment efficiency of the GEM is of great significance.

\subsection{Model Design}

In order to further discuss the influence of the efficiency of $R \& D$ investment on the enterprise performance of the GEM, we use the DEA model to calculate the efficiency of R\&D investment, as the independent variables. Use the OLS multiple regression model to discuss the influence of the efficiency of the R\&D investment on enterprise performance and the moderating effect of the managerial power on the relationship between the R\&D investment efficiency and enterprise performance. The model is shown as below.

$$
\begin{aligned}
& R_{0 A} A_{i, t}\left(R_{O} O E_{i, t}\right)=\beta_{0}+\beta_{1} C R S T E_{i, t}+\beta_{2} I N S T_{i, t}+\beta_{3} C E O P O W E R_{i, t}+\beta_{4} S I Z E_{i, t}+\beta_{5} F C F_{i, t}+\beta_{6} G R O W T H_{i, t} \\
& +\beta_{7} \text { BIND }_{i, t}+\beta_{8} F I R S T_{i, t}+\beta_{9} L E V_{i, t}+\beta_{10} A G E_{i, t}+\beta_{11} \text {Relation }_{i, t}+\beta_{12} \sum_{j=1}^{8} I N D_{i, t}+\beta_{13} \sum_{y=1}^{3} Y E A R_{i, t}+\varepsilon \\
& \operatorname{ROA}_{i, t}\left(\operatorname{ROE}_{i, t}\right)=\beta_{0}+\beta_{1} \operatorname{CRSTE}_{i, t}+\beta_{2} \operatorname{CRSTE}_{i, t} \times \mathrm{SOE}_{i, t}+\beta_{3} \mathrm{SOE}_{i, t}+\beta_{4} I N S T_{i, t} \\
& +\beta_{5} \text { CEOPOWER }{ }_{i, t}+\beta_{6} \mathrm{SIZE}_{i, t}+\beta_{7} F_{C F} F_{i, t}+\beta_{8} G R O W T H_{i, t}+\beta_{9} \text { BIND }_{i, t}+\beta_{10} F_{I R S T} i_{i, t} \\
& +\beta_{11} L E V_{i, t}+\beta_{12} A G E_{i, t}+\beta_{13} \text { Relation }_{i, t}+\beta_{14} \sum_{j=1}^{8} I N D_{i, t}+\beta_{15} \sum_{y=1}^{3} Y E A R i, t+\varepsilon \\
& \operatorname{ROA}_{i, t}\left(\operatorname{ROE}_{i, t}\right)=\beta_{0}+\beta_{1} C R S T E_{i, t}+\beta_{2} C R S T E_{i, t} \times C E O P O W E R_{i, t}+\beta_{3} C E O P O W E R_{i, t} \\
& +\beta_{4 I N S T_{i, t}}+\beta_{5} S I Z E_{i, t}+\beta_{6} F_{C F} F_{i, t}+\beta_{7} \text { GROWTH }_{i, t}+\beta_{8} B_{\text {BND }}{ }_{i, t}+\beta_{9} \text { FIRST }_{i, t} \\
& +\beta_{10} L E V_{i, t}+\beta_{11} A G E_{i, t}+\beta_{12 \text { Relation }_{i, t}+\beta_{13}} \sum_{j=1}^{8} I N D_{i, t}+\beta_{14} \sum_{y=1}^{3} Y E A R_{i, t}+\varepsilon
\end{aligned}
$$

Model (1) examined the relationship between $R \& D$ capability and enterprise performance, Model (2) joined the variable of property nature, research the difference of R\&D capability and enterprise performance between state-owned and non-state-owned enterprise. Model (3) reviewed the moderating effect of managerial power. If regression coefficient of $\mathrm{CRSTE}_{\mathrm{i}, \mathrm{t}} \times \mathrm{CEOPOWER}_{\mathrm{i}, \mathrm{t}}$ is significant, it means the managerial power has a moderating effect. 


\subsection{Variable Declaration}

(1) Explained variable. This paper utilizes the rate of return on total assets and the rate of return on net assets to measure enterprise performance. Due to the lag of R\&D investment, therefore, using the data index lagging 1 year.

(2) Test variable: the R\&D capability. Define the input and output indicators and use the DEA model to calculate. As shown in Table 3.

(3) Moderator variable. It used whether chairman and general manager is one person to measure. If the board of directors and general manager join together, it means the managerial power is too much, set to 1 , otherwise 0 .

(4) Control variables. Select the data which affect the enterprise performance and R\&D capability. Including: size, lev, inst, fcf, growth, bind, first, relation, age, year, ind, soe. As shown in Table 3.

Table 3. Symbol and Definition of Variables

\begin{tabular}{|c|c|c|}
\hline $\begin{array}{c}\text { Variable } \\
\text { Types }\end{array}$ & Symbol & Definition \\
\hline \multirow{2}{*}{$\begin{array}{l}\text { Explained } \\
\text { Variable }\end{array}$} & ROA & $\begin{array}{l}\text { total profit } \div \text { balance of total assets at the end of the } \\
\text { period }\end{array}$ \\
\hline & ROE & $\begin{array}{l}\text { net profit } \div \text { balance of owner's equity at the end of } \\
\text { the period }\end{array}$ \\
\hline $\begin{array}{l}\text { Test } \\
\text { Variable }\end{array}$ & CRSTE & $\begin{array}{l}\text { the comprehensive technical efficiency of enterprise } \\
\text { which calculated by the data envelopment analysis } \\
\text { (DEA) }\end{array}$ \\
\hline \multirow[t]{7}{*}{$\begin{array}{l}\text { Moderator } \\
\text { Variable }\end{array}$} & CEOPOWER & $\begin{array}{l}\text { if the board of directors and general manager join } \\
\text { together, set to } 1 \text {, otherwise } 0\end{array}$ \\
\hline & SOE & $\begin{array}{l}\text { if it is the state - owned enterprise, set to1, otherwise } \\
0\end{array}$ \\
\hline & INST & $\begin{array}{l}\text { the quantity of institutional investors holding } \\
\div \text { Issued and outstanding shares }\end{array}$ \\
\hline & SIZE & natural logarithm of the total asset \\
\hline & FCF & $\begin{array}{l}\text { (the net cash flow that generated from company } \\
\text { business activities - cash flow generate from } \\
\text { purchasing fixed assets) } \div \text { the total asset }\end{array}$ \\
\hline & GROWTH & $\begin{array}{l}\text { (the final operating income-the initial operating } \\
\text { income) } \div \text { the initial operating income }\end{array}$ \\
\hline & BIND & $\begin{array}{l}\text { the number of the independent director } \div \\
\text { the board's total membership }\end{array}$ \\
\hline \multirow[t]{7}{*}{$\begin{array}{l}\text { Control } \\
\text { Variable }\end{array}$} & FIRST & $\begin{array}{l}\text { the number of the first largest shareholder } \div \text { issued } \\
\text { and outstanding shares }\end{array}$ \\
\hline & LEV & $\begin{array}{l}\text { total liabilities at the end of current period } \div \text { total } \\
\text { assets in current period }\end{array}$ \\
\hline & RELATION & $\begin{array}{l}\text { dummy variable of political relation, if the enterprise } \\
\text { has the political relation, set to } 1 \text {, otherwise } 0\end{array}$ \\
\hline & AGE & the age of company \\
\hline & & $\begin{array}{l}\text { dummy variable. According to the guidelines of the } \\
\text { classification of industry of listed companies, the }\end{array}$ \\
\hline & IND & $\begin{array}{l}\text { GEM is divided into } 13 \text { industry categories, use the } \\
\text { reference of manufacturing industry, and set } 8 \\
\text { dummy variables. }\end{array}$ \\
\hline & YEAR & $\begin{array}{l}\text { dummy variable, use the reference of the year } 2010 \text {, } \\
\text { and set } 3 \text { dummy variables from } 2011 \sim 2013\end{array}$ \\
\hline
\end{tabular}




\section{Test Results and Analysis}

\subsection{Descriptive Statistics}

Table 4. The Descriptive Statistics of Main Variables

\begin{tabular}{ccccccc}
\hline Variable & Mean & Median & Std. Dev & Min & Max & Observations \\
\hline ROA & 0.057608 & 0.0521 & 0.0500 & -0.0974 & 0.2067 & 572 \\
ROE & 0.082352 & 0.0742 & 0.0702 & -0.1772 & 0.3336 & 572 \\
CRSTE & 0.273046 & 0.2118 & 0.2097 & 0.0203 & 1 & 572 \\
CEOPOWER & 0.452797 & 0 & 0.4982 & 0 & 1 & 572 \\
INST & 0.1457 & 0.1081 & 0.1473 & 0.000011 & 0.7222 & 572 \\
SIZE & 20.8742 & 20.7913 & 0.5469 & 19.7733 & 22.2191 & 572 \\
FCF & -0.0538 & -0.0439 & 0.0839 & -0.3538 & 0.1224 & 572 \\
GROWTH & 0.2624 & 0.2244 & 0.3000 & -0.4363 & 1.2196 & 572 \\
BIND & 0.3695 & 0.3333 & 0.0508 & 0.3333 & 0.6000 & 572 \\
FIRST & 0.3294 & 0.3095 & 0.1276 & 0.0889 & 0.6148 & 572 \\
LEV & 0.1899 & 0.1549 & 0.1351 & 0.0188 & 0.6191 & 572 \\
RELATION & 0.2535 & 0 & 0.4354 & 0 & 1 & 572 \\
AGE & 8.9091 & 9 & 4.2754 & 1 & 20 & 572 \\
\hline
\end{tabular}

It can be seen from Table 4, the maximum and the minimum of the rate of return on total assets and the rate of return on net assets has a certain gap. The average of $R \& D$ investment efficiency of listed companies is 0.2730462 from 2010-2013. It means the enterprises should improve the efficiency of $R \& D$ input and output. The minimum value and maximum value of the R\&D capability are 1 and 0.02 and it means the difference of R\&D capability of different enterprises is far. The average value of the managerial power is 0.4527972 , and standard deviation is 0.4982026 , and it shows the indicator data have a greater degree of dispersion and more than half of the chairman and general manager are separate working. The proportion of independent directors is 0.3694 , close to one-third of the directors. The average shareholding of the first big shareholder is 0.3294 , and it means the GEM exist one predominant phenomenon.

\subsection{An Empirical Analysis of Managerial Power, R\&D Capabilities and Enterprise Performance}

Managerial power, R\&D capability and the enterprise performance: we use Model (1) examined the impact of $R \& D$ capabilities on the enterprise performance. First, make the entire sample regression, and then join the cross-validation of property nature. Under the different property rights, analyze the relationship between the R\&D capabilities and enterprise performance. The OLS regression results is shown in Table 5, through the test of model 1, the regression coefficient of R\&D capability on the enterprise performance of the ROA and ROE are respectively 0.080296, 0.0299753 and significant at $1 \%$ and $5 \%$ level, which means that $R \& D$ capability has positive influence on enterprise performance. Support for the hypothesis H1. After joining the cross-validation of property nature, the relationship between the two is significant positive correlation, and it proved that the conclusion is robustness. Model 2 join the property rights as cross-validation, and the correlation coefficient of the CRSTExSOE is -0.0978892 , and significant at $1 \%$ level, it means the property right has a negative moderating effect on the relationship between R\&D capability and the enterprise performance. In other words, compared with the state-owned enterprises, higher R\&D capability of Non-state-owned enterprises, have the greater positive influence on enterprise performance. Non-state-owned enterprises 
managers are likely to be the owner of the enterprise and to focus on the influence of $\mathrm{R} \& \mathrm{D}$ investment projects on the enterprise performance. And the state-owned enterprises, investment decisions are greatly influenced by the macro and micro government policy. Many other factors influenced the impact of the R\&D capability on the enterprise performance. Thus relationship between the two is weakened, support for the hypothesis H1.

Table 5. Nature of Property Right, R\&D Capability and the Enterprise Performance

\begin{tabular}{|c|c|c|c|c|}
\hline \multirow{2}{*}{ Variables } & \multicolumn{2}{|c|}{ ROA } & \multicolumn{2}{|c|}{ ROE } \\
\hline & Model 1 & Model 2 & Model 1 & Model 2 \\
\hline _CONS & $\begin{array}{c}0.1448883^{*} \\
(1.82)\end{array}$ & $\begin{array}{c}0.1307224^{*} \\
(1.65)\end{array}$ & $\begin{array}{c}-0.0484248 \\
(-0.42)\end{array}$ & $\begin{array}{c}-0.067357 \\
(-0.58)\end{array}$ \\
\hline CRSTE & $\begin{array}{c}0.080296 * * * \\
(9.06)\end{array}$ & $\begin{array}{c}0.0892745 * * * \\
(-3.28)\end{array}$ & $\begin{array}{c}0.0299753 * * \\
(2.33)\end{array}$ & $\begin{array}{c}0.0406806^{* * * *} \\
(3.03)\end{array}$ \\
\hline SOE & & $\begin{array}{c}0.0201206^{*} \\
(1.70)\end{array}$ & & $\begin{array}{c}0.0314318^{*} \\
(1.82)\end{array}$ \\
\hline CRSTE $\times$ SOE & & $\begin{array}{c}-0.0978892 * * * \\
(-3.28)\end{array}$ & & $\begin{array}{c}-0.1160499 \\
(-2.66)\end{array}$ \\
\hline CEOPOWER & $\begin{array}{c}-0.0046493 \\
(-1.33)\end{array}$ & $\begin{array}{c}-0.0041303 \\
(-1.17)\end{array}$ & $\begin{array}{c}-0.0040441 \\
(-0.79)\end{array}$ & $\begin{array}{c}-0.0028857 \\
(-0.56)\end{array}$ \\
\hline INST & $\begin{array}{l}0.0215097 \\
(1.75)\end{array}$ & $\begin{array}{l}0.0174496 \\
(1.41)\end{array}$ & $\begin{array}{l}0.0019683 \\
(0.11)\end{array}$ & $\begin{array}{c}-0.0039534 \\
(-0.22)\end{array}$ \\
\hline SIZE & $\begin{array}{c}-0.0035359 \\
(-0.96)\end{array}$ & $\begin{array}{c}-0.0030368 \\
(-0.83)\end{array}$ & $\begin{array}{l}0.0078416 \\
\quad(1.47)\end{array}$ & $\begin{array}{l}0.0084818 \\
\quad(1.6)\end{array}$ \\
\hline FCF & $\begin{array}{c}0.1501899 * * * \\
(6.97)\end{array}$ & $\begin{array}{c}0.1497498 * * * \\
(7.01)\end{array}$ & $\begin{array}{c}0.2118356 * * * \\
(6.76)\end{array}$ & $\begin{array}{c}0.2116781 * * * \\
(9.57)\end{array}$ \\
\hline GROWTH & $\begin{array}{c}0.0388033 * * * \\
(6.40)\end{array}$ & $\begin{array}{c}0.039616 * * * \\
(6.59)\end{array}$ & $\begin{array}{c}0.0830655 * * * \\
(9.43)\end{array}$ & $\begin{array}{c}0.0839795 * * * \\
(9.57)\end{array}$ \\
\hline BIND & $\begin{array}{c}-0.0830935 * * \\
(-2.32)\end{array}$ & $\begin{array}{c}-0.0721868 * * \\
(-2.02)\end{array}$ & $\begin{array}{c}-0.1011564 * * \\
(-1.95)\end{array}$ & $\begin{array}{c}-0.0855309 \\
(-1.64)\end{array}$ \\
\hline FIRST & $\begin{array}{c}-0.0316468 * * \\
(-2.19)\end{array}$ & $\begin{array}{c}-0.0359118^{* *} \\
(-2.48)\end{array}$ & $\begin{array}{l}0.0165144 \\
\quad(0.79)\end{array}$ & $\begin{array}{l}0.0102696 \\
(0.49)\end{array}$ \\
\hline LEV & $\begin{array}{c}-0.0387039 * * * \\
(-2.65)\end{array}$ & $\begin{array}{c}-0.0396853 * * * \\
(-2.74)\end{array}$ & $\begin{array}{c}-0.1053141 * * * \\
(-4.96)\end{array}$ & $\begin{array}{c}-0.1061334 * * * \\
(-5.02)\end{array}$ \\
\hline RELATION & $\begin{array}{c}-0.003038 \\
(-0.74)\end{array}$ & $\begin{array}{c}-0.0028327 \\
(-0.7)\end{array}$ & $\begin{array}{c}-0.00728356 \\
(-1.22)\end{array}$ & $\begin{array}{c}-0.006977 \\
(-1.17)\end{array}$ \\
\hline AGE & $\begin{array}{c}0.0012039 * * * \\
(2.87)\end{array}$ & $\begin{array}{c}0.0011293 * * * \\
(2.71)\end{array}$ & $\begin{array}{l}0.0004311 \\
\quad(0.71)\end{array}$ & $\begin{array}{l}0.0003399 \\
(0.56)\end{array}$ \\
\hline INDUSTRY & control & control & control & control \\
\hline YEAR & control & control & control & control \\
\hline $\mathrm{N}$ & 572 & 572 & 572 & 572 \\
\hline Adjusted $\mathrm{R}^{2}$ & 0.3224 & 0.3343 & 0.2734 & 0.2800 \\
\hline F-statistic & $25.69 * * *$ & $23.05^{* * * *}$ & $20.83 * * *$ & $18.08 * * *$ \\
\hline
\end{tabular}

Note: $\mathrm{t}$ statistics in parentheses $* * * \mathrm{p}<0.01,{ }^{* *} \mathrm{p}<0.05$, $* \mathrm{p}<0.1$.

R\&D capability and the enterprise performance: influence of the managerial power. Table 6 use model (3) test the relationship of managerial power, R\&D capability and the enterprise performance, we can see from the result of regression, and the correlation coefficient of the CRSTExCEOPOWER is -0.0517614 , and the significant is at $1 \%$ level, it means managerial power has a negative moderating effect on the relationship between $R \& D$ capability and enterprise performance. This shows that with the increase of managerial power, it would weaken the influence of $R \& D$ capability on the enterprise performance, and verifies the hypothesis H2. Reason may be that the 
greater the managerial power, the constraint of decision-making is less, where the managers have a high degree of freedom, and limit the information processing capacity of the board, which weakens the supervision function of the board of directors. Affect the validity and objectivity of the direction of enterprise technology innovation strategy. At the same time increasing speculation of the executive and agency cost. Ultimately inhibit the action of the $R \& D$ capability which improves the enterprise performance.

Table 6. Managerial Power, Research and Development Capability and Enterprise Performance

\begin{tabular}{|c|c|c|c|c|c|c|}
\hline \multirow[t]{2}{*}{ Variables } & \multicolumn{2}{|c|}{ The Whole Sample } & \multicolumn{2}{|c|}{$\begin{array}{c}\text { State-Owned } \\
\text { Enterprises (Model 3) }\end{array}$} & \multicolumn{2}{|c|}{$\begin{array}{c}\text { Non-State-Owned Enterprises } \\
\text { (Model 3) }\end{array}$} \\
\hline & ROA & ROE & ROA & ROE & ROA & ROE \\
\hline \multirow{2}{*}{ _CONS } & $0.1763 * *$ & -0.0317 & -1.0504 & 0.7519 & $0.1689 * *$ & -0.0638 \\
\hline & $(2.21)$ & $(-0.27)$ & $(-0.91)$ & $(0.50)$ & $(2.08)$ & $(-0.53)$ \\
\hline \multirow{2}{*}{ CRSTE } & $0.1041 * * *$ & $0.0426^{* *}$ & 0.0194 & -0.0741 & $0.1139 * * *$ & $0.0552 * * *$ \\
\hline & $(8.90)$ & (2.49) & $(0.28)$ & $(-0.82)$ & $(9.26)$ & (3.03) \\
\hline CRSTEX & $-0.0518 * * *$ & -0.0276 & -0.1403 & -0.1228 & $-0.0529 * * *$ & -0.0326 \\
\hline CEOPOWER & $(-3.08)$ & $(-1.12)$ & $(-1.24)$ & $(-0.84)$ & $(-3.03)$ & $(-1.26)$ \\
\hline \multirow{2}{*}{ CEOPOWER } & $0.0095^{*}$ & 0.0035 & 0.0929 & 0.0759 & $0.0104 *$ & 0.0055 \\
\hline & $(1.65)$ & $(0.42)$ & $(1.60)$ & $(1.01)$ & $(1.75)$ & $(0.63)$ \\
\hline \multirow{2}{*}{ INST } & $0.0244 * *$ & 0.0035 & -0.0332 & -0.1196 & $0.0260 * *$ & -0.0008 \\
\hline & (1.99) & $(0.20)$ & $(-0.60)$ & $(-1.68)$ & (1.97) & $(-0.04)$ \\
\hline \multirow{2}{*}{ SIZE } & -0.0052 & 0.0070 & 0.0503 & -0.0305 & -0.0051 & 0.0082 \\
\hline & $(-1.40)$ & (1.29) & $(0.95)$ & $(-0.45)$ & $(-1.35)$ & $(1.46)$ \\
\hline \multirow{2}{*}{ FCF } & $0.1565 * * *$ & $0.2152 * * *$ & 0.0944 & 0.1710 & $0.1533 * * *$ & $0.2131 * * *$ \\
\hline & $(7.28)$ & $(6.84)$ & $(0.66)$ & $(0.92)$ & $(7.00)$ & $(6.56)$ \\
\hline \multirow{2}{*}{ GROWTH } & $0.0390 * * *$ & $0.0831 * * *$ & 0.0216 & $0.0811 * *$ & $0.0410 * * *$ & $0.0860 * * *$ \\
\hline & (6.47) & (9.44) & $(0.87)$ & $(2.51)$ & (6.55) & (9.26) \\
\hline \multirow{2}{*}{ BIND } & $-0.0897 * *$ & $-0.1047 * *$ & -0.2157 & -0.1307 & $-0.0714 * *$ & -0.0836 \\
\hline & $(-2.53)$ & $(-2.01)$ & $(-0.63)$ & $(-0.29)$ & $(-1.99)$ & $(-1.57)$ \\
\hline \multirow{2}{*}{ FIRST } & $-0.0334 * *$ & 0.0156 & 0.2607 & 0.1173 & $-0.0414 * * *$ & 0.0066 \\
\hline & $(-2.33)$ & $(0.74)$ & $(1.56)$ & $(0.54)$ & $(-2.81)$ & $(0.30)$ \\
\hline \multirow{2}{*}{ LEV } & $-0.0358 * *$ & $-0.1038 * * *$ & 0.0032 & 0.1375 & $-0.0381 * *$ & $-0.1076^{* * *}$ \\
\hline & $(-2.46)$ & $(-4.88)$ & $(0.03)$ & $(0.83)$ & $(-2.60)$ & $(-4.95)$ \\
\hline \multirow{2}{*}{ RELATION } & -0.0032 & -0.0074 & -0.0455 & -0.0523 & -0.0030 & -0.0058 \\
\hline & $(-0.80)$ & $(-1.24)$ & $(-1.40)$ & $(-1.25)$ & $(-0.73)$ & $(-0.94)$ \\
\hline \multirow{2}{*}{ AGE } & $0.0010 * *$ & 0.0003 & 0.0052 & -0.0003 & $0.0008 * *$ & 0.0002 \\
\hline & $(2.41)$ & $(0.53)$ & $(1.28)$ & $(-0.06)$ & (1.99) & $(0.33)$ \\
\hline INDUSTRY & control & control & control & control & control & control \\
\hline YEAR & control & control & control & control & control & control \\
\hline $\mathrm{N}$ & 572 & 572 & 31 & 31 & 541 & 541 \\
\hline Adjusted $\mathrm{R}^{2}$ & 0.3325 & 0.2737 & 0.0931 & 0.1746 & 0.3560 & 0.2831 \\
\hline F-statistic & 24.70 & 18.93 & 1.25 & 1.51 & 25.92 & 18.81 \\
\hline
\end{tabular}

Note: $t$ statistics in parentheses $* * * p<0.01, * * \mathrm{p}<0.05$, , $\mathrm{p}<0.1$.

The correlation coefficient of the CRSTE $\times$ CEOPOWER of the state-owned enterprises is -0.1403152 , but is not significant, so it means state-owned enterprises under the control of the government. When the managerial power is larger, it will be subject to the constraint of the government power, so it will partly offset too much managerial power on the influence on the relationship between $R \& D$ capability and enterprise performance. Therefore, the negative moderating effect of the managerial power of the state-owned enterprise on the relationship between R\&D capability and enterprise performance was not significant.

The correlation coefficient of the CRSTEXCEOPOWER of the non-state-owned enterprises is -0.0528939 , and is significant. It means the greater the managerial power of the non-state enterprise, the smaller the supervision and constraint. It maybe exists the phenomenon of lack of investment on the high R\&D efficiency projects, which affect the maximization goal of the enterprise value. Compared with the state-owned enterprises, the managerial power of non-state-owned enterprises has a more negative moderating effect 
on the relationship between $R \& D$ capability and the enterprise performance. Support for the hypothesis $\mathrm{H} 1$.

\subsection{Robustness Test}

To test the reliability of this article conclusion, perform the following robustness test. Replace the rate of return on total assets and the rate of return on net assets for the Tobin $\mathrm{Q}$ index and the main business profitability. Meanwhile, replace the R\&D capability index with the number of application patent and the number of invention patent. Regression result is essentially consistent with the above study conclusion, which means that above study conclusion has strong robustness.

\section{Concluding Remarks}

The paper takes a sample of four years of the GEM companies from 2010 to 2013, and uses the DEA model for the quantitative analysis of the GEM R\&D capabilities. Take the $\mathrm{R} \& \mathrm{D}$ capability for independent variables. Under the different property rights, use the OLS multiple regression analysis model which considered the relationship between $R \& D$ capabilities and enterprise performance. And under the different property rights, the moderating effect of the managerial power on the relationship between $R \& D$ capability and enterprise performance.

\subsection{The Analysis of the R\&D Investment Efficiency}

Since the year 2010, R\&D efficiency of the GEM increased, but the value of R\&D efficiency between the largest R\&D efficiency is still having a certain gap. And most companies too much rely on the promoting of the increasing state of enterprise scale efficiency. The improvement of technical efficiency needs further development.

\subsection{R\&D Capability and the Enterprise Performance: Concurrently Discuss the Managerial Power}

The conclusion of this paper can be summarized as follows: first, the efficiency of $R \& D$ investment is positive relation to firm performance, and it shows that GEM with strong R\&D capability would be a better corporate performance; second, managerial power has a negative moderating effect on the relationship between R\&D capability and firm performance. When one person are chairman and general manager, it leads to bringing out asymmetric information, increase agent cost of shareholders and managers, which can't be conducive to the improvement of the efficiency of R\&D projects, and further affect firm performance. The main significance of the conclusion of this paper is as follows:

(1) Managerial power is a double-edged sword. Distributing authority reasonably could promote the positive interaction between executives and directors, and further to improve the quality of strategic decision. When one person is chairman and general manager, and it leads to the person has more power. This would affect on boards of director's independence and contribution to enterprise value, and increase agent cost of management. Board of directors should exert its functions and effect in adjusting dynamically resource allocation of managerial power according to revenue and cost of managerial power, improving enterprise R\&D capability, making the correct decision of technological innovation and promoting the long-term development of enterprises. (2) Meanwhile, to improve technological innovative capabilities of enterprises, and we should begin with improving the effect of executive stock-based incentives from the micro aspect. Also, the interests of management should be linked to the goal of maximizing shareholders 'value, and to reduce the short-term speculative behavior and pay attention to the long-term development goal of the enterprise. (3) It should avoid 
duality of chairman and general manager, dispense managerial power, establish the appropriate proportion of internal directors, increase the proportion of external directors and strengthen the supervising function of the enterprise.

In this paper, it inevitably has some limitations. In the selection of the sample, some of the listed companies on GEM did not disclose R\&D investment data index in the report, and be unable to distinguish whether $R \& D$ company have been engaged in $R \& D$ investment activities. This brings out the errors from the selection of a sample that may be influences on the calculation of R\&D capability, and further influence the effect of the managerial power on the relationship between $R \& D$ capability and enterprise performance.

\section{Declarations}

Authors' contributions

Feng Gu collected the listed companies' data, conducted the econometric statistical analysis, and wrote the first full draft of the paper. Lin Zhang secured funding for the work, handled the final editing and polishing of the paper before submission, and handled the revisions after reviewing comments. Both authors read and approved the final manuscript.

\section{Competing Interests}

The authors declare that they have no competing interests.

\section{Acknowledgements}

This work was supported by National Social Science Fund of China (No. 15BGL038).

\section{References}

[1] Z. Griliches, "Market value, R\&D, and patents", Economics letters, vol. 7, no. 2, (1981), pp. 183-187.

[2] A. G. Hu and G. H. Jefferson, "Returns to research and development in Chinese industry: Evidence from state-owned enterprises in Beijing", China Economic Review, vol. 4, no.15, (2004), pp. 86-107.

[3] B. Los and B. Verspagen, "R\&D spillovers and productivity: evidence from US manufacturing micro data", Empirical economics, vol. 25, no.1, (2000), pp. 127-148.

[4] J. L. Garner, J. Nam and R. E. Ottoo, "Determinants of corporate growth opportunities of emerging firms," Journal of Economics and Business, vol. 54, no.1, (2002), pp. 73-93.

[5] S. C. Chang, S. S. Chen and C. W. Lin, "The Influence of corporate internal governance on the wealth effect of R\&D expenditure increases", 2006 NTU International Conference on Finance, Taiwan, (2006) December 13-14.

[6] K. H. Chung, P. Wright and B. Kedia, "Corporate governance and market valuation of capital and R\&D investments", Review of Financial Economics, vol. 12, no.2, (2003), pp. 161-172.

[7] B. H. Hall and R. Orianib, "Does the market value R\&D investment by European firms? Evidence from a panel of manufacturing firms in France, Germany, and Italy", International Journal of Industrial Organization, vol. 24, no.5, (2006), pp. 971-993.

[8] R. A. Connlly and M. Hirschey, "Firm size and the effect of R\&D on Tobin's q", R\&D Management, vol. 35, no.2, (2005), pp. 217-223.

[9] S. A. Le, B. Walters and M. Kroll, "The moderating effects of external monitors on the relationship between R\&D spending and firm performance”, Journal of Business Research, vol. 59, no.2, (2005), pp. 278-287.

[10] R. Fishman, "Estimating the value of political connections", American Economic Review, vol. 91, no.4, (2001), pp. 1095-1102.

[11] S. Johnson and T. Mitton, "Cronyism and capital controls: evidence from Malaysia", Journal of Financial Economics, vol. 67, no.2, (2003), pp. 351-382.

[12] M. Faccio, "Politically connected firms", American Economic Review, vol. 96, no.1, (2006), pp. 369-386.

[13] J. L. Y. Ho, A. Wu and S. X. Xu, "Corporate governance and returns on information technology investment: Evidence from an emerging market," Strategic Management Journal, vol. 32, no.6, (2011), pp. 595-623. 


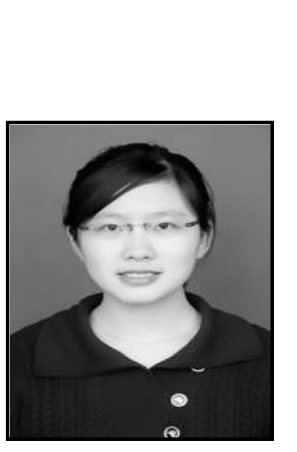

\begin{abstract}
Authors
Feng Gu, she received her M.S. degree (2012) in Accounting from Harbin Commercial University. Now she is a lecturer at School of Accountancy of Harbin Commercial University. Her current main research interests include theory and method of financial accounting, corporate governance.
\end{abstract}

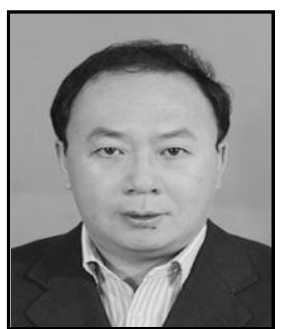

Lin Zhang, he received his M.S. degree (1999) in Economics from Heilongjiang University and Ph.D degree (2012) in Management Science and Engineering from Wuhan University of Technology. Now he is a professor at School of Accountancy of Harbin Commercial University. His current main research interests include theory and method of financial accounting, technology innovation. 